\title{
Halal Vaccine and the Ethical Dimension of Vaccination Programmes
}

\author{
Ahmad Badri bin Abdullah*
}

By 2017, Malaysia plans to be the main global producer of halal vaccines as announced by its Minister of International Trade and Industry, Mustapa Mohamed, at the World Halal Forum 2014 in Kuala Lumpur. A Saudi corporation, he added, has already invested USD 100 million in the Halal Industry Development Corporation (HDC) to produce halal vaccines for meningitis, hepatitis, and meningococcal. ${ }^{1}$

Despite such development, only less than a year ago, the Health Exco of Penang state government in a press statement denounced parental refusal to vaccinate their children primarily due to religious reasons. He pointed out that the government's immunisation requirement has met with scepticism from parents, especially middle class parents. ${ }^{2}$ The Exco's concern is valid and legitimate given the risk associated with the lack of vaccination, such as a fatal case involving an unvaccinated four-year-old child due to diphtheria, as the child's parents were doubtful of the safety, efficacy, as well as the halal status of vaccines. ${ }^{3}$ These instances beg a question as to how the new halal vaccines industry in Malaysia would address the ethical predicaments in vaccination.

Recently, ethical considerations on vaccination are increasingly highlighted pertaining to the design of its implementation such as the proper role of governments in developing, promoting, and monitoring vaccination programmes, conducting research on human subjects, ensuring the long-term access to vaccines, as well as the identification of the risks and benefits of vaccines. The 'herd immunity', which indicates the protection against diseases due to the high vaccination rates in a community is also a related ethical issue. Therefore, the decision made by any individual either to decline or to accept vaccination will not only engender his own vulnerability to diseases, but also affect the community at large. Moreover, the other ethical objection to vaccination is the 'preventive problem', which elucidates the concern of inequitable distribution of benefit and harm from the preventive medicine's focus on population-based interventions. Dawson suggests that such measure is attributable to several key elements, whose ethical values are at stake:

(a) This preventive measures are performed on healthy individuals.

(b) Such public health intervention often carries some risk of harms.

(c) The benefits of such measure are enjoined by the society at large, whereas the risk of harms are on the shoulders of individuals. ${ }^{4}$ 
From an Islamic point of view, medical action must fulfil any of the higher purposes of Shariah (maqāssid al-sharī'ah) to be considered ethical. In this sense, Abul Fadl Mohsin Ebrahim explicates that vaccination satisfies all the five essentials of Shariah's objectives. Within the ambit of the preservation of religion (hifz al-dīn), he suggests that vaccinated Muslims are in better position to uphold the obligatory acts of worships due to their healthy body. The universal access to safe vaccines has portrayed the success stories of preserving the life (hifz al-nafs) of millions of people across nations. Parents who vaccinated their child so as to safeguard them from the vaccine-preventable diseases have indeed fulfilled the objective of preserving the family unit (hifz al-nasl). By enjoying the peace of mind affirming that their family and community are protected from vaccine-preventable diseases, those who resort to vaccination have satisfied the objective of the preservation of intellect (hifz al-'aql). Finally, vaccination programmes may contribute to the preservation of national wealth (hifzal-māl), as it offers a cost effective measure to prevent disease rather than having to treat its symptoms. ${ }^{5}$

Nonetheless, ethical conformity of vaccination with the principles maqāṣid al-sharì'ah alone seems insufficient in dealing with such a complex and multidimensional issue. Therefore, it is suggested here that the main principles of medical ethics, along with their Islamic accounts, need to be employed so as to offer more tangible proposals. The said principles are three: autonomy, beneficence, and justice. ${ }^{6}$

In Western biomedical ethics, the notion of autonomy implies that the decision of a patient needs to be accepted by a physician even if it is wrong. By contrast, Islam views individual welfare as closely related to that of the family and community. Hence, the validity of an individual's autonomy is contingent upon its effects on the other two institutions. A physician may thus refuse to implement a patient's decision for a certain treatment or vice versa he may implement a certain treatment refused by the patient by referring to his own conscience. This however, does not mean that the patient's autonomy has been compromised in vaccination requirement, as it is strongly suggested that medical staffs must professionally explain to parents the need for such measure in public health programme as well as the related benefits and risks to their children. Nevertheless, some researchers has suggested that parents should be given the right to refuse for children to be vaccinated, where the risk to the child is small and the risk that an unvaccinated child poses to the vaccinated child is relatively small as well. ${ }^{7}$ Interestingly this preference for parental authority over state authority may be elucidated by an Islamic legal maxim, which asserts that:

"Private authority is stronger than public authority". 
The principle of beneficence in which the idea of maximising benefits and minimising possible harms be found, is rather in conformity with Islamic concept of safeguarding benefits (jalbu al-masālih) and preventing harm (dar'u almafäsid). Moreover, the execution of harm can only be justified with the aim to bring a greater benefit. This is somehow similar to one Islamic legal maxim regarding the weight of benefit and harm:

\section{"Greater benefit is prioritised over the lesser harm".}

It is suggested that the best interest of a child in vaccination is contingent upon the degree of vaccine coverage. If more than 95 per cent of children in a particular country are vaccinated, the chance of an unvaccinated child to contract a vaccine-prevented disease is relatively low. Therefore, to vaccinate such a child will imply an ethical cost due to the risk of its side effects. In the case that the average is less than 80 per cent where there is no herd-immunity, vaccination is a valid ethical choice as the risks of vaccine-preventable diseases become endemic. In this case, the benefit of the vaccinated children of having the protection from diseases outweighs the very risk of suffering the side effects. Nonetheless, by referring to current development of scientific research, the best interest of a child could be served through the course of vaccination and to live in the optimal vaccine coverage area. ${ }^{10}$

Justice here entails the right to equal treatment or vaccination regardless of differences in age, gender, ethnicity, nationality, ability to pay and so forth. With the majority of the vaccine supplies are from the limited numbers of multinational corporations, it is still obscure how this may suffice to meet the ascending demands in the future. This is where the attempt of Malaysia to embark on the halal vaccine manufacturing industry might provide a solution for the scarcity of vaccine in Muslim societies especially the underdeveloped Muslim endemics countries with high rates of unvaccinated children.

Malaysia's attempt to become the main halal vaccine producer is undoubtedly a commendable initiative. It may reduce the rising suspicion and distrust among the Muslim communities to the course of vaccination. In spite of that, it is also imperative that all stakeholders take into account several ethical drawbacks, which have been long associated with such public health preventive programme. Being provided with the principles of the higher objectives of Shariah and contemporary medical ethics as the guiding lights of its path, such initiative is expected to eventually bring about socio-economic benefits not only for Muslims, but also to all Malaysians. 


\section{Notes}

* Ahmad Badri bin Abdullah, Research Fellow at IAIS Malaysia, with a focus on maqasid al-shari 'ah (the higher objective of Shariah), usul al-fiqh, and contemporary Islamic jurisprudence discourse. He is pursuing his $\mathrm{PhD}$ in the study of maslahah. (Email: badri@iais.org.my)

1. Courtney Trenwith, "Halal vaccines could be available in 3 years," Arabian Business.com, available online at http://www.arabianbusiness.com/halalvaccines-could-be-available-in-3-yrs-545957.html (accessed on 15 May 2014).

2. Opalyn Mok, "Under fire, vaccine deniers defend their choice," The Malay Mail Online, (29 July 2013), available online at http://www.themalaymailonline.com/ malaysia/article/under-fire-vaccine-deniers-defend-their-choice (accessed on 23 May 2014).

3. Syafinaz Amin Nordin et.al, "Parental Refusal to Diphteria Vaccine: A Fatal Outcome," Medical Journal of Malaysia 68, no. 5 (Oct 2013), 431.

4. Angus Dawson, "Vaccination and Preventive Problems," Bioethics 18, no. 6 (November 2004), 518.

5. Abul Fadl Mohsin Ebrahim, "Vaccination in The Context of Maqasid alShariah and Islamic Medical Jurisprudence," Arabian Journal of Business and Management Review 3, no.9 (2014), 45.

6. Ingela Kantz et al, "Ethics and Vaccination," Scandinavian Journal of Public Health 32, no.3 (June 2014).

7. Peter Bradley, "Should Child Immunisation be compulsory?" Journal of Medical Ethics 25, 1999, 330-334.

8. Jalāl al-Dīn 'Abd al-Rahmān al-Suyūti, al-Ashbāh wa al-Naẓā'ir, (Riyādh \& Mecca: Maktabah Nazār Mustafa al-Bāz, 1418H), 251.

9. 'Izz al-Dīn ibn 'Abd al-Salām, Qawā' id Al-Kubra/ Qawā 'id al-Ahkām fì Masālīh al-Anām, (Damascus: Dār al-Qalam, 1412H), v.1, 8.

10. Cf., Ingela Kantz et al, "Ethics and Vaccination," 176. 